\title{
MENUMBUHKAN JIWA BERWIRAUSAHA
}

\author{
Oleh : Slamet"
}

\begin{abstract}
Abstak
Para wirataha adalah orang-orang yang mempmyai kemampuan melihat dan menilai kesempatan-kesempatan yang ada, mengumpulkan sumber-sumber daya yang dibutuhkan guna mengambil keuntungan daripadanya dan mengambil tindakan yang tepat guna memastikan sukses. Para wirausaha adalah individn-individu yang berorientasikepada tindakan, dan bermotivasi tinggi yang mengambil resiko dalam mengejar mjuanna.
\end{abstract}

Kata Kunci: Jiwa, Wiransaha, Sukses

\section{A. Pengertian Kewirausahaan}

Istilah wirausaha/wiraswasta yang sebelumnya sering dipakai daripada istilah wirausaha sebagai padanan kata entrepreneur. Istilah wiraswasta sendiri mulai ramai dibicarakan sekitar tahun 1970-an, pada awal bangsa Indonesia secara sungguh-sungguh membangun kembali perekonomian nasionalnya secara bertahap melalui program Pelita (Pembangunan Lima Tahun). Secara etimologis, wiraswasta merupakan suatu istilah yang berasal dari kata-kata wira dan swasta. Berbagai pengertian wiraswasta pada dasar, adalah

Wira berarti utama, gagah, hhur, berani, teladan dan pejuang

Swa berarti sendiri

Sta berarti berdiri

Swasta berarti berdiri di atas kaki sendiri atau kemampuan untuk berdiri sendiri"

Jadi seorang wirausaha dapat diartikan sebagai seorang yang berkemaun keras dalam melakukan tindakan yang bermanfaat dan patut menjadi teladan hidup. Sehingga dapat dideskripsikan sebagai seorang wirausaha, jika mempunyai dan memakai atribut: (1) wawasan komersial dan kesadaran akan pasar; (2) kemampuan untuk bekerja secara tekun dan mandiri; (3) pikiran yang inovatif dan kreatif; (4) kemampuan untuk memanajemeni dan mengarahkan perubahan; (5) kapasitas mengorganisasi dan ketrampilan analitik; (6) stamina dan daya tahan; dan (7) kemampuan untuk bergaul yang baik dengan orang dari segi tingkatan (Tarmudji, 1996).

* Penulis adalah Pembantu Dekan I Fakultas Ekonomi UIN Malang 
Dengan demikian wiraswasta/wirausaha berarti pejuang yang gagah, luhur, berani dan pantas jadi teladan dalam bidang usaha. Selanjutnya, disebut dengan wiraswasta adalah keberanian mengambil resiko, keutamaan, kreatifitas. dan keteladanan dalam menangani usaha atau pekerjaan dengan berpijak pada kemauan dan kemampuan sendiri, Dalam hal ini, pengertian wiraswasta bukanlah teladan dalam usaha partikelir, melainkan adalah sifat-sifat keberanian, keutamaan, keteladanan, dan semangat yang bersumber dari kekuatan diri sendiri, dari seorang pendekar kemajuan, baik dalam kekaryaan pemerintahan maupun dalam kegiatan apa saja di luar pemerintah dalam arti positif yang menjadi pangkal keberhasilan seseorang (Sumahamijaya, 1980).

Wiraswasta juga mencakup semua aspek pekerjaan termasuk staf pemerintah (pegawai negeri), koperasi, badan usaha milik Negara (BUMN), petani, TNI, Polri, dan lain sebagainya. Soesarsono menyarankan untuk kepentingan ini maka istilah yang dapat digunakan adalah wirakarya, sementara wiraswasta digunakan untuk kepentingan swasta atau usaha. Namun lebih lanjutnya apapun istilah yang dipakai, baik di dunia pemerintahan maupun swasta, yang terpenting adalah aspek kemandirian. Syis dalam (Soesarsono, 1987) memberikan pengertian istilah wiraswasta sebagai suatu kepribadian ung gul yang mencerminkan budi yang luhur dan suatu sifat yang patut diteladani, karena atas dasar kemampuan diri sendiri dapat melahirkan suatu sumbangsih karya untuk kemajuan kemanusiaan yang berlandaskan kebenaran dan kebaikan. Selanjutnya, dinyatakan bahwa seorang wiraswasta adalah pejuang kemajuan, mengutamakan berkarya dalam bidang pekerjaan, baik disektor pemerintahan maupun swasta, bersumber pada kemampuan sendiri, didorong oleh inisiatif untuk mewujudkan kesejahteraan keluarga, lingkungan, dan bangsanya.

Wirausaha (entepreneur) adalah mereka yang mendirikan, mengelola, mengembangkan, dan melembagakan usaha secara mandiri, bisa menciptakan kerja bagi orang lain dengan berswadaya. Definisi ini mengandung asumsi bahwa setiap orang yang mempunyai kemampuan normal, bisa menjadi wirausaha asal mau dan mempunyai kesempatan untuk belajar dan berusaha. Siagian (1999) mendefinisikan: "Kewirausahaan adalah semangat, perilaku, dan kemampuan uniuk memberikan tanggapan yang positif terhadap peluang memperoleh keuntungan untuk diri sendiri dan atau pelayanan yang lebih baik pada pelanggan/masyarakat; dengan selalu berusaha mencari dan melayani langganan lebih banyak dan lebih baik, serta menciptakan dan menyediakan produk yang lebih bermanfaat dan menerapkan cara kerja yang lebih efisien, melalui keberanian mengambil resiko, kreativitas dan inovasi serta kemampuan manajemen." Pengertian ini mengandung esensi kewirausahaan yaitu tanggapan yang positif terhadap peluang untuk memperoleh keuntungan untuk diri sendiri dan atau pelayanan yang lebih baik pada pelanggan dan masyarakat, cara 
yang etis dan produktif untuk mencapai tujuan, serta sikap mental untuk merealisasikan tanggapan yang positif tersebut. Secara implisit, bahwa wirausaha tidak hanya orang-orang yang bekerja pada sektor produktif \% pengusaha/ perusahaan\% yang profit oriented, namun juga termasuk orang-orang yang mengelola organisasi nirlaba yang bertujuan untuk memberikan pelayanan yang lebih baik bagi pelanggan/masyarakat.

Sehingga jiwa wirausaha harus dimiliki oleh semua orang bangsa Indonesia tanpa terkecuali pegawai pemerintah yaitu pegawai negeri sekalipun. Untuk mewujudkan keberhasilan jiwa wirausaha, maka harus mampu belajar banyak tentang diri sendiri, jika bermaksud untuk mencapai tujuan yang sesuai dengan apa yang diinginkan dalam hidup ini. Kekuatan jiwa datang dari tindakan-tindakan diri sendiri dan bukan dari tindakan orang lain, sebagaimana dalam al-Qur'an surat Ar'd ayat 11 yang artinya "Sesungguhnya Allah tidak merubah keadaan sesuatu kaum sehingga mereka merubah keadaan yang ada pada diri mereka sendiri". Kegagalan dan resiko merupakan tanggungjawab atas tindakan mereka sendiri, kegagalan harus diterima sebagai pengalaman belajar. Banyak individu berhasil setelah mengalami banyak kegagalan, dengan demikian belajar dari pengalaman akan membantu seseorang menyalurkan kegiatan-kegiatan untuk mencapai hasilhasil yang lebih positif, dan keberhasilan merupakan buah dari usaha-usaha yang tidak mengenal lelah. Orang yang mempunyai jiwa wirausaha harus mau belajar dan bersedia belajar dari pengalaman dan berubah dari waktu ke waktu. Sadar akan selalu cara-cara baru untuk meningkatkan produktivitas diri sendiri. Salah satu kunci utama bagi keberhasilan adalah keterlibatan diri dalam pertumbuhan secara terus menerus (continous growth yourself). Faktor waktu untuk masa kini dan terutama untuk masa mendatang akan sangal menentukan perjalanan seseorang, karena hanya siapa yang dapat menggunaka secara tepat dan efisien akan dapat survive dan maju, sehingga waktu benar-benar penting. Sesungguhnya factor waktu telah tersurat dan tersirat dalam al-Qur'an surat al Ashri yang menyatakan "Sesungguhnya manusia itu akan selalu merugi, kecuali mereka yang berima. Orang yang beriman tidak hanya percaya akan adanya Allah SWT, tetapi juga mematuhi perintah dan larangannya. Hal itu berarti keharusan berbuat yang baik dan meninggalkan sikap mental yang jelek. Dengan demikian waktu merupakan suatu keharusan bagi setiap orang untuk menggunakan waktu sebaikbaiknya.

\section{B. Kepribadian Wirausaha}

Istilah wira lebih mencirikan sikap mental ksatria sehingga tercakup sikap mental yang mulia dan agung, berbudi luhur, berjiwa besar, jujur, pemberani tetapi pemurah hati, dan penuh keteladanari. Namun, wira belüm mencakup pengertian 
kemampuan untuk dapat berdiri sendiri, terutama untuk dapat memperoleh nafkah dan kebutuhan hidup pada zaman modem ini. Sebaliknya istilah "swasta" lebih memberikan pengertian tentang atau asosiasi dengan kemampuan untuk berusaha sendiri dalam bidang ekonomi. Seseorang yang menonjol dalam kewiraannya dapat saja melarat dan serba bergantung dalam segi materi. Sedangkan, seseorang yang menonjol dalam aspek swastanya, mungkin saja mentalnya kurang baik, karena cara dapat juga menghalalkan segala cara. Oleh sebab itu, sikap mental wiraswasta yang tinggi adalah gambaran orang yang ideal, karena kemamuannya untuk dapat mewujudkan kepribadian wira dalam kehidupan yang sukses dalam pemenuhan kebutuhan lahir dan batin, seimbang, selaras dan serasi, baik dalam segi moral spiritual maupun dalam aspek kehidupan lainnya.

Kewiraswastaan banyak menekankan segi kemampuan untuk berdiri sendiri. Pengertian berdiri sendiri dapat ditafsirkan secara kritis dan dinamis, bukan dalam arti harus bekerja seorang diri tanpa berhubungan atau bekerja sama dengan siapa pun. Fenomena saat ini, dalam dunia modern dalam rangka membangun kehidupan harus melalui jaringan-jaringan (networking) dan kerjasama (team work). Akan mengalami kesulitan jika melakukan suatu pekerjaan secaraefisien hanya dilakukan seorang diri. Disamping itu, berdiri sendiri bukan berarti suatu sikap menyendiri atau tertutup, tetapi harus dikaitkan dengan kepercayaan diri yang memang sangat diperlukan untuk dapat mengatasi berbagai tantangan hidup.

Berikut beberapa hal yang harus dimiliki oleh setiap orang dalam membangun jiwa atau kepribadian berwirausaha, antara lain :

\section{Percaya Diri}

Kepercayaan diri (selfconfidence) menunjukkan kemampuan dan tekad dalam menghadapi kehidupan. Kepercayaan diri merupakan faktor penting dalam meraih sukses, dan setiap sukses yang diperoleh akan mempertebal kepercayaan diri yang bersangkutan. Kepercayaan diri adalah sifat internal pribadi seseorang dan bersifat sangat relatif, baik antara orang satu dengan orang lain ataupun seseorang dalam menghadapi tugas yang berbeda.

Dengan bekal kepercayaan diri yang kuat, seseorang akan mampu mempertahankan hidup (survive) dalam menghadapi tantangan dunia global yang penuh dengan persaingan. Berikut beberapa sebab pentingnya kita memiliki sifat percaya diri, yaitu : (1) pribadi yang berguna adalah pribadi yang percaya akan kekuatannya sendiri; (2) bukan orang lain yang menentukan ini salah, baik, buruk, melainkan kemerdekaan pikirannya dan kepercayaan kepada dirinya sendiri yang membuat ketentuan itu; (3) orang lain tidak perlu cemas dan takut, karena jiwa yang bebas selalu mengejar kebenaran; (4) percaya diri merupakan tiap kemerdekaan pribadi dan tiap kemerdekaan bangsa, yang menimbulkan kekuatan tabiat, akhlak dan budi; (5) orang yang percaya kepada dirinya sendiri, tidak merasa 
hina tentang apa yang dikerjakannya, bahkan ia ingin memperoleh kemajuan dalam pekerjaannya; (6) untuk memperoleh keteguhan akhlak tidak sukar, asalkan saja manusia merasa insyaf bahwa ia adalah benar-benar manusia, yang mempunyai kemauan yang lebih tinggi daripada kedudukan; (7) mengejar kebesaran jiwa terlebih dahulu daripada mengejar harta. Harus sadar, bahwa disamping hak, iapun memiliki kewajiban. Jangan lupa bahwa usia riwayat sesudah matinya, jauh lebih lama daripada usia badannya sendiri semasa ia masih hidup (Rustam Effendy).

Tingkat kemandirian atau kemampuan untuk berdiri sendiri erat hubungannya dengan tingkat kepercayaan diri seseorang. Seseorang yang mempunyai kepercayaan diri yang tinggi, relatif akan mampu menghadapi dan menyelesaikan suatu pekerjaan tanpa harus menunggu perintah atau bantuan orang lain, sebagaimana teori motivasi Mc Gregor bahwa orang mempunyai wakat yang disebut dengan teori " $X$ " dan teori " $Y$ ". Kemandirian terutama dalam segi inisiatif dan kemampuan untuk dapat menolong dirinya sendiri dari masalah yang dihadapi. Kepercayaan diri merupakan landasan yang kuat untuk meningkatkan karsa dan karya seseorang. Sebaliknya, setiap karya yang dihasilkan akan menumbuhkan dan meningkatkan kepercayaan diri. Keyakinan dan keberanian saling berkaitan dengan kepercayaa diri dapat tumbuh karena keimanan seseorang. Iman dan bersyukur adalah bagian yang tidak terpisahkan, bahkan menjadi landasan utama dari kepercayaan diri.

\section{Semangat}

Dalam dunia yang penuh dengan persaingan, yang dicirikan dengan dunia global, maka semangat kewirausahaan harus ditumbuhkan kembangkan baik kepada masyarakat yang bekerja di sektor swasta maupun pemerintah. Baik pemimpin/ penguasaha maupun sebagai staf/karyawan. Yang secara khusus adalah : (1) kemauan kuat untuk berkarya dengan semangat mandiri; (20 mampu membuat keputusan yang tepat dan berani mengambil resiko; (3) kreatif dan inovatif; (4) tekun, teliti, dan produktif; dan (5) berkarya dengan semangat kebersamaan dan etika yang sehat (Puslatkop, 1995). Jika seseorang ingin sukses, maka harus mengabdikan diri dengan penuh kesetiaan dan semangat. Supaya hal ini terjadi, maka harus mencintai pekerjaan. Inilah satu-satunya cara supaya seseorang harus rajin. Bukan pengetahuan dan bakat semata, tetapi semangat dan kemampuan yang memberikan inspirasi. Kekurangan senaningatan, maju mundur dan ketidak sabaran bisa disembuhkan, akan tetapi kalau sangsi atau ragu itu menjadi suatu kebiasaan, hal ini sangat menyedihkan dan sungguh sukar untuk diobati. Akibatnya ménjadi lebih buruk lagi, karena sifat ini selalu diikuti dengan kebiasaan-kebiasaan buruk lainnya, seperti kurangnya daya tahan dan daya penerus dan tiada sifatnya keseksamaan dan ketelitian, dan akhirnya mengakibatkan kecurangan dan ketidak jujuran. 
Jika seseorang ingin mencapai lebih banyak dengan tenaga yang miliki, meneliti dan memeriksa diri sendiri dengan seksama. Jika sưdah mengetahui sifatsifat diri sendiri dengan cara analisis SWOT, maka lebih lanjut seseorang harus memelihara dan menggunakannya sedemikian rupa, sehingga bisa berkembang dan tumbuh. Orang yang tegas mula-mula membuat suatu rencana dengan teliti dan hati-hati, kemudian melaksanakannya dengan segera. Orang yang bijaksana hanya melakukan satu pekerjaan saja, dan melakukannya dengan baik-baik, bisa melaksanakan dan keseksamaan diperlukan untuk setiap pekerjaan yang perlu. Ketahuilah, bahwa suatu percobaan yang lemah dan setengah-setengah tidak akan mendatangkan sukses yang anda inginkan. Pusatkan perhatian anda kepada satu bagian saja dan hendaknya usaha setiap hari harus membantu untuk mencapai kemajuan kearah sukses:

Wirasuaha menyusun prioritas dalam sasaran-sasaran karir dan hasil-hasil yang diinginkan harus berkaitan dengan tujuan-tujuan yang dapat diukur dan berarti. Sasaran-sasaran haruslah bersifat menantang dan memberi motivasi untuk belajar dan berkembang dalam karir. Ciri wirasuaha yang penting adalah menawarkan sesuatu yang berguna bagi orang lain.

\section{Kejujuran}

Kejujuran adalah sesuatu yang paling penting bagi pembentukan kepribadian seseorang, sebab hal ini merupakan dasar dari sukses seterusnya. Jika ingin mempunyai kepribadian yang menarik, tentu anda harus berusaha supaya selalu jujur dalam pikiran anda. Anda akan memiliki banyak pengaruh di dunia ini kalau anda terkenal sebagai orang yang jujur. Jika orang dapat dipercaya kejujurannya. jika penyataannya sesuai dengan kenyataan-kenyataan, maka anda akan disegani oleh masyarakat.

Biasakanlah untuk berpikir, berbicara, dan besikap jujur. Jujur dalam maksud anda dan jujur dalam tingkah laku anda. Itulah cara sebaik-baiknya untuk mendapatkan kepercayaan umum, sedangkan kepercayaan pada diri sendiri akan bertambah dalam sadar dan insyaf, bahwa anda selalu dibimbing oleh kejujuran. Persaingan dengan cara kotor, beberapa orang sering memberi ujian berat kepada rasa kejujuran anda, akan tetapi sebagai orang yang jujur anda harus tetap hidup berdasarkan pada azas kejujuran itu. Untuk dapat memenangkan persaingan, wirausahawan harus selalu mengucapkan : (1) Saya akan memenuhi semua kewajiban saya, apapun yang terjadi; (2) Saya akan membiasakan diri untuk dengan seksama dan tertib memberikan keterangan saya (3) Saya akan melatih diri supaya perkataan saya sama dengan apa yang saya perbuat; (4) Saya akan memenuhi dengan tepat segala janji-jani saya; (5) Saya menyadari akan menginsyafi tanggung jawab yang saya pikul; dan (6) Saya akan mengadakan persiapan untuk menghadapi keadaan darurat. 
Orang yang jujur mutlak membebask an hati nuraninya supaya leluasa bertindak disegala pemikiran dan tindak tanduknya, sehinggadengandemikian ia menyesuaikan diri dengan hukum alam yang tertinggi. Nafsu untuk mengadakan sebuah spekulasi sering menimbulkan kecurangan-kecurangan dan tindakan-tindakan yang tidak jujur. Anda dapat menanamkan uang anda, akan tetapi anda harus melakukannya dengan cara yang baik dan bijaksana. Selalulah ingat, bahwa dengan berspekulasi akan merugikan kepentingan-kepentingan diri sendiri.

\section{Mawas Diri}

Dalam fungsi manajemen salah satunya adalah fungsi pengawasan, mawas diri identik dengan pengawasan terhadap diri sendiri. Oleh sebab itu, setiap orang harus mengevaluasi atas kelemahan atau kekurangan yang selama ini dirasakan, yang selanjutnyauntuk dapat diperbaikan. Menurut seorang konsultan manajemen, ada kata bijak yaitu "akuilah kelebihan orang lain untuk menjadi perubahan pada diri sendiri". Mawas diri harus dilakukan secara terus menerus setiap saat, hal dapat digunakan untuk meningkatkan kepercayaan diri (selfconfidence) di bidang apapun yang dirasakan lemah.

\section{Ciri-Ciri Wirausaha}

Secara unum dapat dikatakan, bahwa manusia wirausaha adalah orang yang memiliki potensi untuk berprestasi. Is senantiasa memiliki motivasi yang besar untuk maju berprestasi. Dalam kondisi dan șituasi yang bagaimanapun, manusia wirausaha mampu menolong dirinya sendiri di dalam mengatasi permasalahan hidupnya. Dengan kekuatan yang ada pada dirinya, manusia wirausaha mampu berusaha untuk memenuhi setiap kebutuhan hidupnya. Di samping itu, manusia wiraswasta mampu mengatasi kemiskinan, baik kemiskinan lahir maupun kemiskinan batinnya tanpa menunggu pertolongan atau bantuan orang lain. Manusia wirausaha tidak suka bergantung kepada pihak lain di alam sekitarnya. Dalam setiap usaha memajukan kehidupan diri serta keluarga, manusia wirausaha tidak suka hanya menunggu ulurantangan dari pihak lain.

Ada dua ciri penting manusia wirausaha (Puslatkop dan PK, 1995) dengan kriteria : wirausaha tangguh dan wirausaha unggul. Pertama, wirausaha tangguh, bercirikan : (1) berpikir dan bertindak stretejik, adaptif terhadap perubahan dalam berusaha mencari peluang keuntungan termasuk yang mengandung resiko agak besar dan dalam mengatasi masalah; (2) selalu berusaha untuk mendapat keuntungan melalui bergaia keunggulan dalam memuasakan pelanggan; (3) berusaha mengenal dan mengendalikan kekuatan dan kelemahan serta meningkatkan kemampuan dengan sistem pengendalian intern; (4) selalu berusaha meningkatkan kemampuan dan ketangguhan terutama dengan pembinaan motivasi dan semangat kerja serta 
pemupukan permodal. Kedua, wirausaha unggul, antara lain : (1) berani mengambil resiko serta mampu memperhitungkan dan berusaha menghindarinya; (20 selalu berupay a mencapai dan menghasilkan karya bakti yang lebih baik untuk langganan, pemilik, pemasok, tenaga kerja, masyarakat, bangsa dan negara; (3) antisipasif terhadap perubahan dan akomodatif terhadap lingkungan; (4) kreatif mencari dan menciptakan peluang pasar dan meningkatkan produktivitas dan efisiensi; dan (5) selalu berusaha meningkatkan keunggulan dan citra melalui inovasi di berbagai bdiang.

Sementara dalam suatu penelitian tentang standarisasi test potensi kewirausahaan pemuda versi Indonesia (Munawir, 1999) menemukan adanya 1] ciri atau indikator kewirausahaan, antara lain : (1) motivasi berprestasi; (2) kemandirian; (3) kreativitas: (4) pengambilan resiko; (5) keuletan; (6) orientasi masa depan; (7) komunikatif dan reflektif; (8) kepemimpinan; (9) locus on control; (10) perilaku instrumental; dan (11) penghargaan terhadap uang. Salah satu ciri manusia wirausaha adalah berkepribadian kuat, manusia yang berkepribadian kuat memiliki ciri-ciri : (1) memiliki moral yang tinggi; (2) memiliki sikap mental wiraswasta; (3) memiliki kepekaan terhadap arti lingkungan; dan (4) memiliki ketrampilan wiraswasta (Soemanto, 1984).

Sedangkan G. Meredith (1996) mengemukakan bahwa : para wirausaha adalah orang-orang yang mempunyai kemampuan melihat dan menilai kesempatankesempatan yang ada, mengumpulkan sumber-sumber daya yang dibutuhkan guna mengambil keuntungan daripadanya dan mengambil tindakan yang tepat guna memastikan sukses. Para wirausaha adalah individu-individu yang berorientasi kepada tindakan, dan bermotivasi tinggi yang mengambil resiko dalam mengejar tujuannya. Daftar ciri-ciri dan sifat-sifat berikut memberikan sebuah profil dari wirausaha.

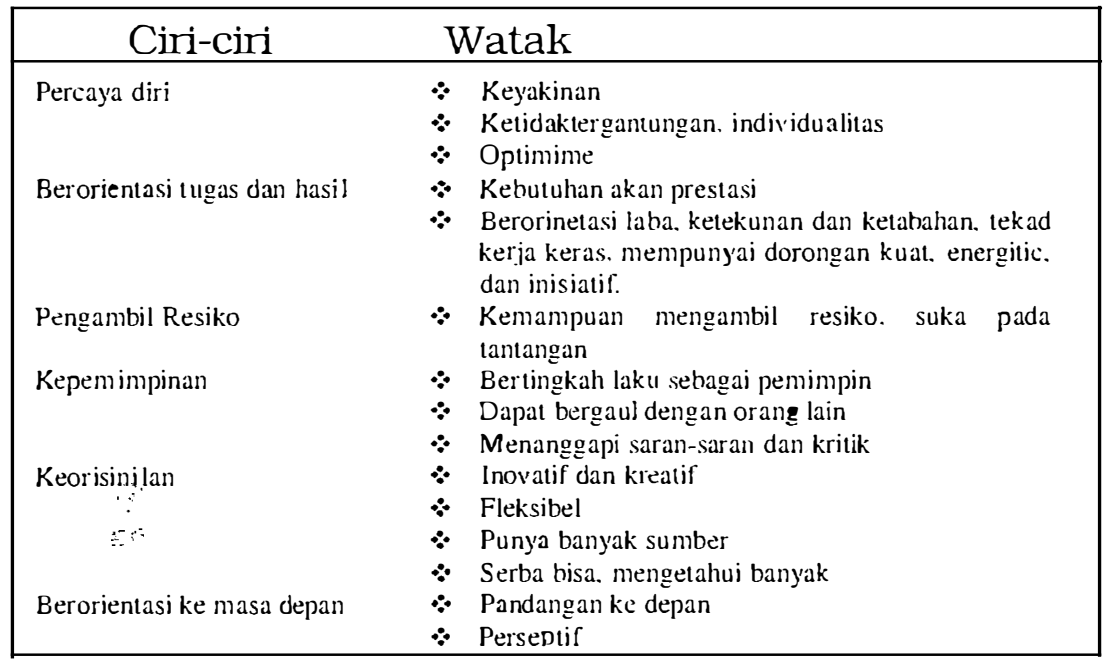




\section{Ketrampilan Wirausaha}

Jiwa wirausaha ada sebagian orang mengatakan itu sebuah pemberian dari Ilahi yang disebut dengan bakat, pernyataan tersebut ada benarnya, namun dengan perkembangan dunia yan' sangat komplek dan global, maka bakat tidaklah cukup untuk membentuk manusia yang mempun yai jiwa wirausaha. Jiwa wirausaha harus dibangun sejak dini baik melalui knowledge maupun skill. Hal ini, merupakan unsur-unsur wirausaha yang meliputi : unsur pengetahuan, unsur ketrampilan, unsur sikap mental, dan unsur kewaspadaan (Soesarsono, 1987,27). Maka untuk menjadikan manusia yang mempunyai jiwa wirausaha diperlukan beberapa ketrampilan. Menurut Soemanto $(1984,63)$ ada lima ketrampilan yang dimiliki oleh orang yang ingin membangun jiwa wirausaha lebih mantap, antara lain : (1) Ketrampilan berpikir kreatif; (2) ketrampilan membuat keputusan; (3) ketrampilan dalam kepemimpinan; (4) ketrampilan manajerial; dan (5) ketrampilan komunikasi (human relations).

Covey menyatakan empat potensial yang dimiliki manusia, yaitu : Pertama; Self awareness, sikap mawas diri. Kedua; Conscience, mempertajam suara hati sehingga menjadi manusia yang berkehendak baik, seraya memunculkan keunikan serta memiliki misi dalam hidup ini. Ketiga; Independen will, pandangan independen untuk bekal bertindak dan kekuatan untuk mentransendensi. Keempat; Creative imagination, berpikir transenden dan mengarah kedepan/jangka panjang untuk memecahkan aneka masalah, dengan imajinasi, khayalan, serta memacu adaptasi yang tepat.

Perbedaan manusia dengan makhluk lain di alam jagad ini adalah karena manusia mempunyai akal yang sempurna, Manusia mempunyai daya pikir atau akal yang relatif jauh lebih tinggi daripada makhluk lain di muka bumi ini. Manusia dapat menciptakan dan membuat berbagai produk dengan menggunakan daya pikirnya. Suatu bangsa yang maju adalah bangsa yang mampu mengembangkan dan menggunakan daya pikirnya. Daya pikir hanya akan berkembang dan dapat digunakan untuk menciptakan sesuatu jika yang bersangkutan mau dan berusaha untuk mengembangkannya. Manusia adalah pusat pemikiran (thingking centre) yang dapat mengawali sesuatu dari daya pikirnya. Daya pikir manusia dapat menghasilkan ide-ide yang tidak terbatas jumlah dan ragamnya. Karena kemampuan ini pula setiap saat manusia dapat menciptakan sesuatu yang baru dalam pikirannya, dan membimbingnya untuk dapat menghasilkan karya yang baru pula. Mengasah otak dengan melatih berpikir kritis dan kreatif akan mendorong seseorang menjadi benar-benar kreatif. Manusia dikatakan kreatif jika dapat membuktikan dirinya sebagai orang yang memang banyak menghasilkan karya yang relatif baru. Sesuatu yang baru sekali, mungkin tidak ada, sesuatu yang dianggap baru adalah hasil suatu induksi, modifikasi, atau hasil kombinasi dari yang lama dengan yang baru, atau 
sebagai hasil pengembangan dari apa yang telah ada sebelumnya.

Jiwa wirausaha harus didukung oleh cara-cara berpikirnya yang kreatif. Pemikiran kreatif itu sendiri didukung oleh dua hal, yaitu : pengerahan daya imajinasi dan proses berpikir ilmiah. Dengan pemikiran yang kreatif, manusia dapat memecahkan berbagai macam permasalahan. Oleh karena itu kreatifitas harus dimiliki oleh semua orang dalam membangun sukses dalam kehidupan. Kemajuan, baik secara organisasi maupun individu sangat ditentukan oleh seberapa jauh kreatifitas yang dikembangkan oleh manusia itu sendiri.

Setiap orang secara sadar atau tidak setiap hari, setiap jam, setiap detik selalu berhadapan dengan keputusan. Baik keputusan sistematis maupun yang tidak sistematis. Pembuatan keputusan diartikan sebagai mengidentifikasi dan memilih serangkaian tindakan untuk menghadapi masalah tertentu atau mengambil keuntungan dari suatu kesempatan. Pembuatan keputusan menghubungkan keadaan saat ini dengan tindakan yang akan diambil di masa yang akan datang dalam kurun waktu yang relatif. Pengalaman masa lalu - poisitif dan atau negatif - memainkan bagian penting dalam menentukan pilihan mana yang dapat digunakan secara layak. Masalah yang berbeda membutuhkan tipe pembuatan keputusan yang berbeda. Ada dua cara tipe pengambilan keputusan (Stoner, 1996:245) yaitu : keputusan terprogram dan keputusan yang tidak terprogram. Keputusan terprogram dibaut dalam kaitannya dengan kebijakan, prosedur, peraturan tertulis atau tidak tertulis yang menyederhanakan pembuatan keputusan dalam situasi yang terjadi berulang kali dengan membatasi atau mengeluarkan alternatif baik yang komplek maupun yang sederhana. Sementara keputusan tidak terprogram berkaitan dengan masalah yang tidak biasa atau merupakan perkecualian. Bila masalah jarang muncul untuk mencakup oleh suatu kebijakan atau demikian penting yang memerlukan perlakukan khusus, maka harus ditangani sebagai keputusan tidak terprogram.

\section{E. Membangun Etos Kerja Kewirausahaan}

Salah satu sumber bala yang menimbulkan bencana nasional akhir-akhir ini adalal karena tidak dimilikinya etos kerja yang memadai bagi bangsa kita. Belajar dari negara lain, Jerman dan Jepang yang luluh lantak di PD II. Tetapi kini, lima puluhtahun kemudian, mereka menjadi bangsa termaju di Eropa dan Asia. Mengapa? Karena etos kerja mereka tidak ikut hancur. Yang hancur hanya gedung-gedung, jalan, dan infrastruktur fisik.

Max Weber menyatakan intisari etos kerja orang Jerman adalah : rasional. disiplin inggi. kerja keras, berorienasi pada kesuksesan material. hemat dan bersahaja, tidak mengumbar kesenangan, meinabung dan investasi. Di Timur, orang Jepang menghayati "bushido" (etos para samurai) perpaduan Shintoisme dan Zen Budhism. Inilah yang disebut oleh Jansen H. Sinamo (1999) 
sebagai "karakter dasar budaya kerja bangsa Jepang".

Ada 7 prinsip dalam bushido, ialah : (1) $G i$ : keputusan benar diambil dengan sikap benar berdasarkan kebenaran, jika harus mati demi keputusan itu, matilah dengan gagah, terhormat, (2) $Y u$ : berani, ksatria, (3) Jin : murah hati, mencintai dan bersikap baik terhadap sesama, (4) Re : bersikap santun, bertindak benar, (5) Makoto : tulus setulus-tulusnya, sungguh-sesungguh-sunggulnnya, tanpa pamrih, (6) Melyo : menjaga kehormatan martabat, kemuliaan, dan (7) Chugo : mengabdi, loyal. Jelas bahwa kemajuan Jepang karena mereka komit dalam penerapan bushido, konsisten, inten dan berkualitas.

Indonesia mempunyai falsafah Pancasila, tetapi gagal menjadi etos kerja bangsa kita karena masyarakat tidak komit, tidak inten, dan tidak bersungguh-sungguh dalam menerapkan prinsip-prinsip Pancasila dalam kehidupan sehari-hari. Maaf cakap "Ketuhanan Yang Maha Esa" misalnya, sering ditampilkan sebagai "Keuangan yang maha kuasa". Kemanusiaan yang adil dan beradab, diterapkan menjadi "Kekuasaan menentukan apa yang adil dan siapa yang beradab", "Persatuan Indonesia" prakteknya menjadi "persatuan pejabat dan konglemerat" dsb. Inilah bukti dari ramalan Ronggowarsito dan inilah zaman edan.

Dampak kondisi ini etos kerja yang berkembang adalah etos kerja asal-asalan. Beberapa pernyataan berikut adalah gambaran ungkapan yang sering muncul ke permukaan yang menggambarkan etos kerja asal-asalan, atau istilah Sinamo (1999) sebagai "etos kerja edan", ialah : (1) bekerjalah sesuai keinginan penguasa, (2) bekerja sebisanya saja, (3) bekerja jangan sok suci, kerja adalah demi uang, (4) bekerja seadanya saja nggak usah ngoyo, tak lari gunung dikejar, (5) bekerja harus pinter-pinter, yang penting aman, (6) bekerja santai saja mengapa harus ngotot, (7) bekerja asal-asalan saja, wajar-wajar saja, kan gajinya kecil, (8) bekerja semau gue, kan di sini saya yang berkuasa. Ungkapan-ungkapan seperti tersebut di atas menggambarkan tidak adanya etos kerja yang pantas untuk dikembangkan apalagi menghadapi persaingan global. Maka dari itu wajarlah jikabangsa ini harus menerima pil pahit bencana nasional krisis yang berkepanjangan yang tak kunjung usai.

Untuk mencapai kualifikasi Wirausaha Unggul maka SDM Perusahaan harus memiliki Etos Kerja Unggul. Jansen H. Sinamo (1999) mengembangkan 8 Etos Kerja Unggulan sebagai berikut :

1. Kerja itu suci, kerja adalah panggilanku, aku sanggup bekerja benar. Suci berarti diabdikan, diuntukkan atau diorientasikan pada Yang Suci. Penghayatan kerja semacam ini hanya mungkin terjadi jika seseorang merasa terpanggil. Bukan harus dari Tuhan, tapi bisa juga dari idealisme, kebenaran, keadilan, dsb. Dengan kesadaran bahwa kerja adalah sebuah panggilan suci, terbitlah perasaan untuk melakukannya secara benar.

2. Kerja itu sehat, kerja adalah aktualisasiku, aku sanggup bekerja keras : Maksudnya adalah bekerja membuat tubuh, roh dan jiwa menjadi sehat. 
Aktualisasi berarti mengubah potensi menjadi kenyataan. Aktualisasi atau penggalian potensi ini terlaksana melalui pekerjaan, karena kerja adalah pengerahan energi bio-psiko-sosial. Akibatnya kita menjadi kuat, sehat lahir batin: Maka agar menjadi maksimal, kita akan sanggup bekerja keras, . bukan kerja asal-asalan atau setengah setengah.

3. Kerja itu rahmat, kerja adalah terimakasihku, aku sanggup bekerja tulus .

Rahmat adalah karunia yang diberikan oleh Yang Maha Kuasa. Respon yang tepat adalah bersyukur dan berterima kasih. Ada dua keuntungan dari bekerja sebagai rahmat, (1) Tuhan memel ihara kita, dan (2) disamping secara finansial kita mendapat upah, juga ada kesempatan belajar, menjalin relasi sosial, dsb. Pemahaman demikian akan mendorong orang untuk bekerja secara tulus.

4. Kerja itu amanah, kerja adalah tanggung jawabku, aku sanggup bekerja tuntas :

Melalui kerja kita menerima amanah. Sebagai pemegang amanah, kita dipercaya, berkompeten dan wajib melaksanakannya sampai selesai. Jika terbukti mampu, akhlak terpercaya dan tanggung jawab akan makin menguat. Di pihak lain hal ini akan menjadi jaminan sukses pelaksanaan amanah yang akan menguklir prestasi kerja dan penghargaan. Maka tidak ada pekerjaan yang tidak tuntas.

5. Kerja itu seni/permainan, kerja adalah kesukaanku, aku sanggup bekerja kreatif :

Apapun yang anda kerjakan pasti ada unsur keindahan, keteraturan, harmoni, artistik seperti halnya seni. Untuk mencapai tingkat penghayatan seperti itu dibutuhkan suatu_kreativitas untuk mengembangkan dan menyelesaikan setiap masalah pekerjaan. Jadi bekerja bukan hanya mencari uang, tetapi lebih pada mengaktualisasikan potensi kreatif untuk mencapai kepuasan seperti halnya pekerjaan seni.

6. Kerja itu ibadah, kerja adalah pengabdianku, aku sanggup bekerja serius

Tuhan mewajibkan manusia beribadah (dalam arti ritual) dan beribadah (dalam artian kerja yang diabdikan pada Tuhan). Kerja merupakan lapangan konkrit melaksanakan kebajikan seperti: untuk pembangunan bangsa, untuk kemakmuran, untuk demokrasi, keadilan, mengatasi kemiskinan, memajukan agama, dsb. Jadi bekerja harus serius dan sungguh-sungguh agar makna ibadah dapat teraktualisasikan secara nyata sebagai bentuk pengabdian pada Tuhan.

7. Kerja itu mulia, kerja adalah pelayananku, aku sanggup bekerja sempurna Secara moral kemuliaan sejati datang dari pelayanan. Orang yang 
melayani adalah orang yang mulia. Pekerjaan adalah wujud pelayanan nyata bagi institusi maupun orang lain. Kita ada untuk orang lain dan orang lain ada untuk kita. Kita tidak seperti hewan yang hidup untuk dirinya sendiri. Manusia moral seharusnya mampu proaktif memikirkan dan berbuat bagi orang lain dan masyarakat. Maka kuncinya ia akan sanggup bekerja secara sempurna.

8. Kerja itu kehormatan, kerja adalah kewajibanku, aku sanggup bekerja unggul :

Sebagai kehormatan kerja memiliki lima dimensi : (1) pemberi kerja menghormati kita karena memilih sebagai penerima kerja (2) kerja memberikan kesempatan berkarya dengan kemampuan sendiri, (3) hasilkaryayang baik memberi kita rasa hormat, (4) pendapatan sebagai imbalan kerja memandirikan seseorang sehingga tak lagi jadi tanggungan atau beban orang lain, (5) pendapatan bisa menanggung hidup orang lain. Semuanya adalah kehormatan. Maka respon yang tepat adalah menjaga kehormatan itu dengan bekerja semaksimal mungkin untuk menghasilkan mutu setinggi-tingginya. Dengan unggul di segala bidang kita akan memenangkan persaingan.

\section{DAFTAR PUSTAKA}

Gepffrey G. Meredith, 1996, Kewirausahaan (Teori dan Praktek), Pustaka Binaman Pressessindo, Jakarta

Justin, dkk, 2001, Kewirausahaan (Manajemen Usaha Kecil), Salemba Empat, Jakarta

Roger Cartwright, 2003, Pribadi Entrepreneur, Prestasi Pustaka, Jakara

Puslatkop dan PK, 1995, Kewirausahaan Indonesia. Departemen Koperasi dan Pembinaan Pusaha Kecil, Jakart

Tarsis Tarmudji, 1996, Prinsip-Prinsip Wirasusaha. Liberty, Yogyakarta 